\title{
New Organizational Forms of Contemporary Public Management: A Brief Analysis of Recent Experience of Mozambique
}

\author{
Albino Alves Simione ${ }^{1}$ \\ ${ }^{1}$ Professor at Pedagogical University and St. Thomas University, Head of Territorial Administration and Local \\ Government Department, Provincial Government of Gaza, Mozambique \\ Correspondence: Albino Alves Simione, Governo da Província de Gaza, Secretaria Provincial, Departamento de \\ Administração Territorial e Autárquica, Av. Samora Machel, s/n, Caixa Postal 108, Cidade de Xai-Xai, \\ Moçambique. Tel/Fax: 258-282-22598, E-mail: simialves@gmail.com
}

\author{
Received: March 4, 2013 Accepted: April 10, 2013 Online Published: September 29, 2013 \\ doi:10.5539/par.v2n2p148 URL: http://dx.doi.org/10.5539/par.v2n2p148
}

\begin{abstract}
This theoretical essay is dedicated to present the constituent elements and characteristics of bureaucracy as a form of organization of public administration. In a second step discusses the criticism of the ideal typical bureaucratic dysfunctions related from the perspective that defends its lack of flexibility and efficiency in the process of functioning of organizations. We discuss also the contemporary current that underlie the new forms of administration, New Public Management and Interactive Governance and exposes some experiments related to the adoption of these new standards of public management in the context of the Mozambican public administration. Their preparation was based on the literature on the concepts of bureaucracy, the new public management approaches and experiences of the management of the Mozambican context. Concludes the existence of changes in the model and patterns of public management in the country, especially with the implementation of the public administration reform (2001-2011).
\end{abstract}

Keywords: bureaucracy, state reform, new public management, interactive governance

\section{Introduction}

The purpose of this essay is to present a theoretical appellant discussion in the organizational studies that public management models, and is related to the debate on the transition from bureaucracy and the emergence of new organizational patterns in contemporary public management. It is the result of a literature review that addresses the processes of public administration reform that gave rise to these new forms of governance.

It is not intended to exhaust the subject, but merely expose some important themes that permeate the reflections on the processes of changes in public administration primarily in Western countries during the 1980s and 1990s, and more recently in Mozambique after the implementation of the Global Strategy for Public Sector Reform (2001-2011) in order to highlight the theoretical basements and main motivations that explain the changes are going through in the administrative apparatus of the state.

First, the test has its focus on bureaucracy seen as an organizational-administrative apparatus of the public sector as the prospect of Weber (1999). In this view, talks up the purpose of its constituents and on their characterization. Here, we present also the context in which the model of bureaucratic administration was adopted in public administration in Mozambique highlighting their characteristics and their role in management. Then, we present a discussion of critical approaches to the functioning of the bureaucratic model, especially its deviations or malfunctions exposed in the wake of the arguments of authors such as Lapassade (1967), Crozier (1981) and Olsen (2007).

Note that some experiences are exposed on the analysis of the functioning of bureaucratic management model implemented in Mozambique since 1975, illustrating the one hand, the influences of the reform movement of the state of the eighties to the formation of the critical monolithic structure of state administration, on the other, showing the trends of changes that signal the streamlining of management, implemented the reforms introduced by the Reform Program of the Local Government (PROL) in 1991.

Subsequently, it is an incursion on the ideas of the movement that inspired the changes in public administration, carried out from the reforms that have occurred in the international context in the eighties as measures to reduce 
inefficiencies in the functioning of bureaucratic administration. In this respect, we present the theoretical foundations that outline some contemporary conceptions of the purpose of public sector management, raised by new concepts explained in the movement of New Public Management (NPM).

In this line of argument, we articulate approaches such New Public Service (NPS) and the Interactive Governance (IG) as a standard of public management should be preferred in the context of contemporary public administration. In this respect, we present the implications of these two theoretical approaches in the Mozambican public administration, by analyzing the recent process of public sector reform initiated by the government with the approval of the Global Strategy for Public Sector Reform (EGRSP) in 2001, whose purpose is to modernize public management and the adoption of new practices such as accountability, management by objectives and society participation in governance, among others.

It is presented in the concluding remarks of the essay the general understanding that guides the reflections on the transition process of the forms of bureaucratic administration to adopt new standards for contemporary public management.

\section{Bureaucracy and Functioning of Public Administration}

Approaching the concept of bureaucracy ends on the one hand, several analytical dimensions included in a type of domination on the expression of established relationships within a social system, on the other hand, in the empirical perspective the existence of bureaucratic practices contains several notable differences in the contexts of their use a greater or lesser extent depending on the circumstances and factors or components in question. At the administrative level, the bureaucracy demonstrates a form of organization that delineates a character on the structures, processes and procedures adopted and operationalized in the functioning of organizations, and they may be either in the public sector as the private sector.

The emergence of bureaucratic forms of organization and mechanisms of operation of the state apparatus is described in the literature on studies of public administration (Medeiros, 2006; Secchi, 2009) as the result of the need to overcome the excesses and the introduction of changes in the patrimonial administration forms prevalent in the nineteenth century. It is explained that the model of bureaucratic administration was formed in the vicinity of this form of organization and structuring having assumed the central role in the administration of the modern state from the beginning of the twentieth century in order to provide ever more predictability, rationality and control in the treatment of administrative matters of the state.

As exposes Weber (1999) although it was organized and employees equity based on a fidelity to charge non-profit objective impersonal or objective tasks of the state administration was not patrimonial specialized employees lacked the distinction between the private sphere and official. The administration was regarded as the personal property of the holder of power and relations were based on their free will, clientelism and favoritism in the acts and actions of patrimonial administration.

Weber (1999, p. 198) examined the type of rational-legal domination prevalent in the exercise of bureaucratic administration of the state, anchored in the principles of skills fixed and translated into official laws or administrative regulations. Individuals within the bureaucracy would relate to compliance by the regular distribution of activities necessary for the purposes of bureaucratic complex, whose duties are also discriminated properly delimited and fixed the rules so that if one obeys and exercise these rights. In this perspective, the author explains that the power of control is based on personal authority, in the sense that if you obey the rules and not the person.

As a feature, the positions are tied to a hierarchy that corresponds to a sequence of instances that convey a sense of authority and subordination of authorities. In bureaucracy there would be a distinction between the private and public spheres, where staff at your service obeys the separation between resources and other official means of their private property (Weber, 1999, p. 199). Consequently, these employees are skilled and perform their official function within specific positions with general rules that express the existence of a rule in an abstract level. It is understandable, therefore, that the system of rules envisaged in ideal typical bureaucratic bind widely actions and relationships of individuals within the context of public institutions.

The bureaucratic model interpreted by Weber (1999) thus defines the attributes of the organization that the post is a profession that aspires to rule that expresses a personal position, the internal structure of relationships established. The job itself offers a set of standardized guarantees against arbitrariness also performed part, the right to receive compensation according to the nature of the position for which they are conferred prerogatives of a career path, giving the employee the honor and estamental possibility of preserving a rigorous mechanization of the bureaucratic apparatus. 
An important aspect highlighted by Weber (1999, p. 212-213) is the technical character of the state administration in modern hierarchical subordination which is the hallmark of bureaucratic mechanism. The advance of bureaucratic organization is seen as the optimal form for the realization of the principle of division of labor second purely administrative purposes thereby allowing a greater specialization of staff and institutionalization of rules calculable.

In view of Olsen $(2007$, p. 7 ) the Weberian model emphasizes the technical superiority and procedural rationality of bureaucracy. The bureaucratic structure is assumed as one that contributes to the unity and coordination, accuracy and speed, predictability, obedience, loyalty, fairness, cost reduction, the institutional memory and knowledge of files and even continuity in change government. The author explains that the Weberian conception highlights the importance of socialization of managers in an ethos to follow rules, and notes that the bureaucracy cultivate a mindset and a personality so difficult that assumed the initiative and creativity through their obedience obsessive cult following rules and avoid risks.

The bureaucratic management model can be briefly described as consisting essentially of:

a) Tasks or assignments guided by administrative rules written;

b) Division of labor and functions properly established;

c) Positions established in a hierarchical way and supervision of the work;

d) Technical expertise and instruction to perform each job;

e) Employees selected through merit and dedication to the job;

f) Separation of ownership and management;

g) Structure that favors the concentration of the means of service.

It is worth noting according to the interpretation of Merquior (1990, p. 130) that outlines a Weberian ideal typical interpretative analysis of bureaucracy as a result of the larger process of rationalization. In this sense, the bureaucracy tends to be an organizational-administrative apparatus that allows you to present through its mechanisms for structuring a form of management more controlled, hierarchical and focused on efficiency.

However, bureaucracy seen as a model of organization and administration has been criticized, from the perception of its dysfunctions, which shows a tendency for its broad concept while distancing actually limit its ideal expression as a mechanism that guides public administration in the States today. In the following topic to address environment and embody the theoretical foundations of the main criticisms exposed to the bureaucratic model.

\section{Bureaucratization and Critical Factors of Public Management}

The discussions about the problems of bureaucracy reverberated theoretical and empirical analyzes that address the bureaucratic dysfunction as a result of the growth of bureaucracy in the organization and relationships in modern society members. It is on this occasion discussing some of the core ideas built around these criticisms.

The bureaucratic model applied to modern states became hegemonic during the twentieth century and was widely associated with the construction of an administration service to the state, which conform forms of organization liable to introduce a clear distinction between private property and public and thereby, expand the role of government and ensure its effective functioning based on technical rationality (Merquior, 1990).

However, it can be said that in Mozambique the establishment of a government based on the principles of the ideal typical bureaucracy had its achievement with the creation of the new state, a result of independence in 1975. The creation of a Mozambican public administration was accomplished by adopting a political system guided by socialist ideology and linked to a centrally planned economy system (Soiri, 1999). Therefore, the public bureaucracy aimed to realize the vision of a government founded on a political-administrative system centrally planned. The central level played the leading role of the state and public administration leaving the implementation of activities to local levels, the provinces and districts that did not have decision-making autonomy and obeyed the logic of hierarchy and subordination of the bureaucracy.

Several authors (Lapassade, 1967; Morin, 1967; Crozier, 1981; Touraine, 1967) mention that in the context of its operation, the Weberian model is affected by a number of dysfunctions of deeply intricate bureaucratic rationality to the strict observance of the rules and centralized controls that inhibit adaptation, change and creativity beyond the limits previously established in bureaucratic administration.

In his argument, Lapassade (1967) raises two critical aspects about the bureaucratic dysfunctions. The first concerns the fact that the bureaucracy has arisen within a context that gives the formation of an administrative 
system supported a form of authoritarian power expended by all public bodies. The second has to do with the political thought of the hierarchical organization of the state brought in by the bureaucracy that has become hegemonic as a concept applied to examining the political sphere, so to speak, referencing both the power and society mediated by the administration.

According to this view the problem of the state bureaucracy was formed from the high bureaucracy, which preserves the hierarchy, standardization and formalism as its main features. In this sense, the criticism associated with the concept of bureaucracy constitutes around its consideration as a cause of pathological phenomena in the organization and not necessarily driving the proper administration itself. This view is contrary to the sociological ideas of bureaucracy as an ideal type according to Weber (1999), because it becomes an end in itself to exclusively focus on the structure and existing processes within, disregarding its exterior it becomes self above.

To Lapassade (1967, p. 24) the explanation of bureaucratism based, for example, a person's disposition on the functions and roles of the machine from the impersonality and streamlining the organization to function as they are covered. The climate follows a bureaucratic hierarchy and a communication character top to bottom, developing conformist attitudes within the system. A consequence of this analysis is that the bureaucratic model becomes weakened given their limited ability to offer feedback and lack of room for initiative.

Bureaucratic administration is related to what this author means displacement of purposes because it deviates from the original purpose designed, predictability and efficiency, generating also resistance to change caused by the conservatism of the bureaucracy as a defense mechanism of the organization previously established.

According to Morin (1967, p. 33-34) bureaucracy is part of the complex process of structuring the modern world in which the bureaucratic organization "tends to become totalitarian." Points as does Lapassade (1967) with the model that arise within the administrative apparatus phenomena bureaucratic careerism, the same as the displacement of purposes and given her strength she mechanization, hypertrophy and tends to parasitism.

In turn, Touraine (1967, p. 75) sees the bureaucracy around three realities: the first associated with a kind of hierarchical organization of roles and not individuals - rationalization, the second as a function of the type of organizations that meet compliance regulations - bureaucracy, and finally as the power exercised by the leaders of organizations - domination of the device. In view of this author, the bureaucratization of management is related to the creation by the members of the unit rigidity that far from being independent of the ends pursued by them, implies an ideological formalism no longer administratively a dogmatism that principles become is untouchable and unchangeable dogmas and decisions to take leave to inspire them.

According to Crozier (1981, pp. 261-262) has characteristics bureaucracy and oppressive routine which calls the "vicious circle" of bureaucracy, coupled with its structural inability to correct themselves in a systemic way, anchoring in formalistic and conservative strategies of self-protection.

The problem exposed by this author is related to the impossibility of appropriateness of decisions, since the individuals in power of decision stand far above the pressures of those who are affected by decisions. Otherwise, the stiffness of the relationship of each organization with the medium and stiffness in parallel relationship existing between different organizations raises difficult problems of coordination. In this sense, Crozier (1981) explains that organizations need an organizational structure to accomplish their goals and thus promote compliance of individuals who participate.

One consequence of these derived features of the bureaucracy is the stratification within the organization that isolates the upper and the subalterns. Among the impersonal rules and centralization emerges an interesting factor mentioned. Around these two parallel develop relations of power and with it the phenomena of dependence and conflict (Crozier, 1981, p. 278). But the vicious cycle is as feature pointed out by this author, responsible for the poor results and frustrations that develop from the atmosphere of impersonality, centralization and lack of initiative within organizations.

Crozier (1981) explains that the problem of resistance to change and adaptation typical of the bureaucratic rigidity is due to the difficulties in bringing the necessary changes, for example, the isolation between the different levels within the organization makes it almost impossible to make changes permanent, but this ends up happening when it becomes unsustainable dysfunction.

It is worth mentioning that the critical analysis to the bureaucracy in public administration in Mozambique began in the second half of the eighties, particularly with the advent of structural adjustment programs proposed by the Breton Woods institutions in 1987, with the approval of the Economic Recovery Programme (PRE) which aimed to transform the structure of a centrally planned economy of the socialist state, for the adoption of market mechanisms. 
As regards Wuyts (1995) the context of a centralized public administration characterized mainly by weak public institutions, lack of qualified staff and limited financial resources, lack of power for decision making at the level of provinces and districts have made the operation of inefficient bureaucratic management model, a result of the weaknesses and imposed by the system of planned economy which has resulted in the drastic reduction in the quality of services provided to the company and the discrediting of state institutions.

The changes in the structure of government and changes in the state apparatus first started in 1991 with the implementation of the Reform Programme of Local Government (PROL) which sought the creation of administrative units and autonomous decision-making at local level thus embodying the ideas of decentralization of state administration in Mozambique.

It is understood that the bureaucratic administration is unleashed in the process of linking social community life, and separates close relationships between individuals, society or the State. In all these situations it takes characteristics which differ according to the degree of complexity of the organization or administrative adopted in any of the situations referenced. These ways of thinking allows the bureaucracy then analyze the characteristics and tendency of degeneration that may be associated with the formation or displacement of interests and purposes subject to various political, economic and social actualities.

\section{Administrative Reform and Management Debureaucratization}

A brief analysis of the historical development of public administration in modern states shows that the traditional model of administration was institutionalized from the application of the propositions advanced by Weber (1999), who examined the bureaucracy as the ideal typical model of state administration. This is based on the principles of reasonableness and adequacy of means to ends, where the range of efficiency by operating the bureaucracy would be enough to overcome the obstacles experienced in the previous patrimonial state, still formed by pre-bureaucratic structures.

Currently, the bureaucratic model of public administration has received sharp criticism, mainly due to lack of flexibility, creativity and inhibiting the accumulation of malfunctions. As stated by Olsen (2007, p. 11) diagnostic criteria underlying these analyzes of the failures of bureaucracy and streamlining the defending state have varied widely in the literature. According to this author, the critics also have different origins - from anti-authoritarian culture that emerged in the sixties, through the neo-liberal ideas and conservative on the review of budget deficits and economic performance of the 1980s, until the vision spread by the movement favor of "reinventing government" emerged in the 1990s.

Some of these ideas have been prescribed for reducing the role of the state, based on a general skepticism about their capacity as the entity that mediates the main economic relations within society. Others are aimed at making the public administration more flexible, transparent and responsive to citizens' expectations and demands for greater participation in administrative processes and the creation of public-private partnerships in public administration.

In Mozambique specifically, the streamlining of management comes first with the idea that the services provided by public entities located at the local level can be offered through an indirect management with the institutionalization of public bodies vested with competence and autonomy of its management, breaking this way with the principles and requirements of the centrally planned administration. The political and economic transformations occurring in Mozambican society, with the approval of the Constitution in 1990, so liberal pluralist and led to the adoption of new mechanisms of public administration that have reoriented the process of management of public policies and participation in the management of the company.

Olsen (2005, p. 6) explains that the "offensive" against the bureaucratic model is based on the argument that it is inefficient and expensive, with a system of organization and internal operations too rigid. These allegations according to Olsen (2005) are around the lack of preparation of the bureaucratic model to deal with the tasks and circumstances faced by the state and its institutions in the context of contemporary societies. Advocates of this approach is a paradigm shift in how to administer and govern through bureaucracies and hierarchies, to adopt practices inspired by competitive standards and cooperation in policy networks (Börzel, 1998) partially autonomous, participative and more interdependent.

Administrative reforms undertaken during the eighties and nineties initially in developed countries especially the U.S. and UK with a view to reducing the impact of the crisis of the state, which affected the economies of developed countries represent an important milestone in the context of thinking public administration and consequently the negative evaluations that formed around the model of bureaucratic administration.

According explains Larbi (1999), the situation of fiscal crisis has put into question the ideas of Walfare State 
prevailing at the time given the huge budget deficits that have put on the one hand, the state with reduced ability to finance its public policies and to continue to play its essential functions and, secondly, its institutions and weakened with a marked reduction in the quality of services provided to citizens.

According to Rua (1997, p. 141) within this crisis scenario not only the state now has fewer features, but also now has less real power. The solution to overcome this situation could not be limited to the economic sphere, but should extend to the political-administrative model. The central argument of this author is that it becomes important to overcome the inflexibility of bureaucracy as major factors and indicates its inertia

His conservatism, his reluctance to depart from the precedents, their strict adherence to the letter of the law, their behavior refractory to innovation and its widespread conformity to group standards. Changes underway imposed the presence of frames creative, flexible and able to innovate, competitive and committed to improving its performance-oriented society rather than self-referred, with all the motivation resulting from the ability to believe in what they were doing (Rua, 1997, p. 142).

According the comment of Pollitt \& Bouckaert (2000) these factors influenced decisively criticism of the bureaucratic model of public administration that shows little flexible to adapt to major changes and escalating economic and social policy generated by globalization that predominate today. These producers argue that the organizational paradigm of public management in this Weberian bureaucratic model, does not account for the shortcomings generated inside before the panorama of inefficiency, reducing resources from the state and the need to improve the quality of services provided citizens.

These authors also claim that bureaucracy has difficulty keeping up with the demands of democratization of government services, since the rules and bureaucratic rules, do not conform to people's expectations. Therefore, these critical elements pointed to bureaucracy - efficiency, democratization of public service and organizational flexibility have become the essential foundation to implore the administrative changes the paradigm of public management based on conceptions of Weberian bureaucracy.

According Mesquita \& Ferreira (1997, p. 38) bureaucratic model introduced a major reform in the way patrimonialist, however, became conservative view of the problems that emerged in modern society as a result of the political and economic partner. In this perspective, the government became a space of inertia with excessive concentration in bureaucratic procedures, where the rules and the rules have become obstacles to the changes required showing the inadaptability the current model over this period.

To Tohá \& Solari $(1997$, p. 85$)$ the modernization of public administration becomes inevitable and settles to introduce changes in the traditional conception that the best way to conduct the activities of public bodies is to establish "exclusive" of procedures governing its activity and a series of limits and controls to prevent abuses and failures. These authors point out that this new process will change the direction of adopting new criteria that could play this role and indicate a set of measures to be considered such as:

1. The explicit redefinition of the mission of each agency. To adapt the functioning of the organ to its mission, is developed strategic planning, set up goals and objectives, set up activities and programs, clients and users, priorities and deadlines;

2. Definition of economic incentives and sanctions, for professional and institutional behaviors and interests consistent with the stated objectives;

3. Evaluation of results by management indicators, periodic audits and other studies that include consultations with the public-user;

4. Linkage between management evaluation and designation of budgetary resources, policy formulation and the appointment, confirmation or removal of directors.

According to Aragão (1997, p. 112) neoliberal criticism emerged in the 1980s rejected the original Weberian model of public bureaucracy, outlining a negative image about this explained by three main critical aspects that according to the author, the traditional bureaucracy:

1. Neglects the public interest to focus on the particular interests of its members;

2. It does not promote the achievement of socially relevant results, since the formulation and implementation of public policies occur more convenient to their interests, and finally;

3. It is wasteful with respect to public resources, to the extent that, in the political game with the legislature, has a turning radius that allows you to commit excesses. Thus, the bureaucrats would potentially rent seekers, looking to maximize their budgets.

Thus, the bureaucracy came to be regarded as a management model that links the interests of bureaucrats and 
utilities, a view according to this author that shows the inevitability of bureaucratic efficiency.

From these considerations, it can be stated as explained by Olsen (2007) that reducing bureaucracy has become a priority on the agenda of contemporary states. Efforts according to this author consubstantiate in ways that focus on the opening of government to society, reversing the logic of the functioning of the traditional paradigm for changes that promote changes in the relationships between institutions and society, ultimately interpreted as an "inevitable change ".

As mentioned earlier, in the Mozambican context administrative reform of the state and streamlining the management emerged initially in 1991 with PROL as a result of the institutionalization of an economic system with market orientation, which resulted in the introduction of democratic principles such as decentralization, privatization and implementation of economic measures of fiscal adjustment and economic stabilization, as mentioned Wuyts $(1995$, p. 02) framed within a program of support and external aid financed by the IMF and the World Bank.

In this perspective the administrative reforms different arrangements have been presented in the literature on public administration, with the aim of introducing changes and changes in the function of State management. These approaches the theoretical analysis and practice of public administration have made important contributions to understanding the implications for public management contemporaneously. The theme that follows focuses its approach on the main theoretical arguments of these new forms of governance that have been demonstrated.

\section{Implications of New Forms of Contemporary Public Management}

The field of public administration has been affected by various transformations, both from the point of view of theoretical or the practical point of view as a result of various reform processes that have been undertaken by States and the important trait of these profound changes have been conjectured by the movement of New Public Management (NPM) and the ideas of Interactive Governance (IG). Without pretending to exhaust the discussion raised by these theoretical approaches to public management presents this occasion an overview of its main theoretical foundations.

According to Larbi (1999) NPM emerges as an abbreviation for a set of doctrines that have dominated the agenda of public administration reform in the eighties and nineties. According to this author, it is related to several structural changes, organizational and managerial occurring in public services in developed countries. There is, however, a conclusive definition for the notions of NPM being interpreted by various authors from multiple perspectives also consider elements of analysis often distinctive.

Caiden (1994) sees NPM as an ideological system of thought based on ideas generated in the private sector and imported into the public sector. Ferlie et al. (1996) argue about the emergence of a philosophical and ideological perspective that advocates the primacy of markets for the production and delivery of public goods and services. Pollitt \& Bouckaert (2002) talk about a vision, or more an ideology, a set of management approaches and specific techniques borrowed from the private sector into the field of public administration. Barzeley (2000) contextualizes it as an argument administrative seen as "systems shaped nests" of ideas relating to the organizational models can be broken down into sub arguments in that each one allows analysis in accordance with its components, namely doctrines and justifications. These theoretical articulations demonstrate not univocal meaning associated with the concept of NPM.

However, it is understood that the NPM changes the emphasis from traditional public administration, "moving" the state toward public management. The traditional model of organization and delivery of public services based on the principles of the bureaucratic hierarchy, standardization, centralization, direct control and self-sufficiency is replaced in this new aspect of the functioning of public administration by a management services.

As a consequence of this perspective, we proposed new standards of governance aimed at reducing costs and maximizing efficiency of public administration by withdrawing the standardization processes and hierarchies to control the application of the results and raising performance, guidance for the quality of services provided to citizens and decentralization (Larbi, 1999, p. 14).

Actually Mozambican reform process gained greater range with the approval of the Global Strategy for Public Sector Reform (EGRSP) in 2001, supported the proposal and assumptions of new public management on the one hand, with the need to reduce public bureaucracy, professionalism and management by objectives in the administration and, second, as an imperative of incorporating some principles and values of public sector governance such as accountability and participatory management. According to Polidano (1999) this vision of reform is a priority for change that have marked and imposing the redefinition of the functions of the state and its bureaucracy in developing countries since the early eighties. 
According to the EGRSP (2001-2011) the desired changes in the Mozambican public administration account for the need to overcome the difficulties faced in the process of public management expressed first by the inflexibility of bureaucracy, reducing the quality of services provided to citizens and second by the lack of integration of the various reforms along the nineties. In fact, EGRSP (2001-2011) is an integrated reform of the state apparatus and modernization of public management that focuses on administrative decentralization, professionalization and citizen participation in the formulation and implementation of public policies.

Allegations of emerging paradigm in public management are distinguished by highlighting the introduction of reform processes aimed at transforming the public sector, according Abrucio (1997) in order to benefit from the flexibility of the performance of state agencies. The NPM highlights a number of administrative reforms based on proposals that advocate a vision based on market values, often contrasting with the essence of public administration, especially with regard to the primary function to the satisfaction of the public interest.

According to Osborne \& Gaebler (1995, p. 19) as a result of this movement, there was a transformation in the traditional paradigm predominant approach for an administration that appointed the "reinventing government" that incorporated tools and management strategies for essentially public institutions, innovative, entrepreneurial promoting greater results that beyond providing services, become a catalyst structure orientation of public policies that favor the intervention of other actors in the private sector and civil society (Osborne \& Gaebler, 1995, p. 32) .

Despite criticism of the Weberian model, it is understood that the contemporary public management approaches do not completely deny all the principles of bureaucracy, but introducing several adjustments in order to give more flexibility to the government, changing, for example, how to control that fails to focus on administrative processes to consider the results. Party is now the principle that it is possible to develop strategies based on the delegation of administrative authority in charge and the subsequent results as well as the principles of accountability.

In practice, according to the EGRSP (2001-2011) this process of modernization of public administration in Mozambique comprises increasing the efficiency of public administration, it is intended to be a result in medium term within a set of transformations to operate both at the state apparatus either at the level of municipalities. These changes favor as explicit Rondinelli (1990, p. 493), the implementation of a decentralization of public services to local government units, either by creating autonomous agencies or by creating partnerships between the public sector and the private sector or civil society organizations civil, creating public institutes breaking thus with traditional monolithic state administration.

Currently it has been presented an approach that emphasizes the creation of the public interest as an important factor in public administration. According to Denhardt \& Denhardt (2000) considers that this theoretical public administration is simultaneously influenced by a significant set of ideas and practices that show an evolution and changes in the forms of public management, far beyond what is presented from the perspective of NPM. This conception is based on theoretical propositions of New Public Service (NPS), which consists of applying ideas renewed theory of citizenship and civil society, humanism organizational and public administration postmodernist.

It is emphasized in this view that in the public sector serves to citizens and not to customers, as theorists believe the NPM movement, whose central focus is directed towards the adaptation and transfer of technical and managerial mechanisms developed in the private sector. The NPS maintains that citizens are actively involved in governance, in the sense that the public management gives greater attention to collective interests beyond the special interests.

The idea of governance in public sector gains momentum in the new context of the public sector who want more interactive and participatory. It is argued that public managers should be subject to public confidence through three important principles: (a) accountability, (b) the social engagement with a view to strengthening the collective interests and (c) the mutual dependency aligned in elevation common dialogue (Denhardt \& Denhardt, 2000, pp. 552-553).

According to Denhardt \& Denhardt (2000, p, 55) the NPS specifically argues that policies are a complex result of the interests of various groups, interests and opinions. In the new context of the role of government relations becomes, becoming an actor is not exclusive and that controls the company offers services, but adds, negotiates, facilitates and seeks solutions with other private actors and civil society. The public interest is conceived as a concept built collectively, they are shared interests and responsibilities based joint deliberation, where the state promotes articulation and the public interest, justice and equity.

In the same perspective Peci; Pieranti \& Rodrigues (2008, p. 41) explains that the concept of governance is aligned to the new context of the growing democratization of state governance that assumes a more intense importance to link the action of civil society and the private sector in building relationships more complex with the state. The fundamental idea is based on the argument that unlike the approach in adopting managerial techniques of NPM in 
the public sector are changeable forms of relationship of state and society in the process of public administration, stepping up the largest open public institutions to influences and social participation of new actors.

In the Mozambican public administration on the one hand, the trends for the application of the principles of new public management in the organization, structure and functioning of the state apparatus, aim at improving quality in service delivery, the approach of government to citizens and creating their representation at the local level, for example, in villages and towns. On the other, is presented as a fundamental means to introduce the desired changes within the public administration, such as management efficiency, participation in public policy, accountability and assessment results (EGRSP, 2001).

\section{Conclusions}

The reflections presented in this paper aimed to introduce the concept of the bureaucratic model of administration from the Weberian theory and, from this outline the arguments proposed in contemporary studies on the processes of state reform and administrative triggered from the years 1980 and 1990, which originated two major theoretical views and practices that constitute administration proposed new models for public sector organizations, where the movement of New Public Management (NPM) and Interactive Governance (IG).

We started from the exposure of elements essences of bureaucracy and proceeded to their respective characterization exposed in order to present the foundations and theoretical foundations of the traditional model of administration. This placement allowed confront the ideas of bureaucratic rationality consolidated with the establishment of the modern state in the early years of the twentieth century, as exposes Weber (1999) constituted the bureaucratic model as the most appropriate form of state administration, which had absence of distinction between public and private property.

In this context, the process of bureaucratization of the state was discussed from the point of view of the criticism of the bureaucratic model, presented from the dysfunctions and displacements of purposes that are intrinsic. This approach aimed to visualize the critical analyzes consist mainly in the second half of the sixties the bureaucratic model, the face of dysfunction and deviations that occur in relation to its original purpose, a result pointed out by Lapassade (1967), Morin (1967) and Touraine (1967) as derived from the organizational rigidity, which expresses resistance to change generated around the bureaucratic structure of conservatism as a defense mechanism of the established organization.

The understanding that you can have on the Mozambican reality is that the institutionalization of bureaucratic model occurred shortly after independence and the creation of the new state in 1975 and, according to the distinctive features of the processes undertaken during this period, was intended to show that application of a model of bureaucratic management principles aimed at achieving a centrally planned administration, since the State had adopted a political and economic system guided by socialist ideology.

It also talked about the reform processes of State established throughout the 1980s and stood analyzes related to the main criticisms of bureaucratic administration, identified as inflexible to adapt to changes brought about by increasing globalization, technology and of increased demands from society for better services. In the surroundings of these reforms, there are administrative models proposed for the public sector. On the one hand, the New Public Management stands out as the implementation of new principles and management techniques, aimed to impart competitiveness, increase the results and efficiency of public administration. On the other hand, the Interactive Governance presents itself as a model of contemporary management advocated for application in the context of public sector organizations, to promote greater participation of society in the formulation and implementation of public policies.

By way of conclusion it is worth noting that the presentation of theoretical reflections on the new organizational forms in the public sector Mozambican offers empirical evidence on the changes to the bureaucratic model of administration for the implementation of administrative arrangements that show greater decentralization and streamlining of public administration. In fact, if revealed the existence of trends in public sector transformation Mozambique, particularly with the implementation of EGRSP (2001-2011).

This view of change in public administration allowed the creation of mechanisms to ensure fiscal discipline, for example, the creation of the Technical Unit for the Reform of State Financial Management (UTRAFE) and the Financial Management System (SISTAFE), the introduction performance indicators, for example, the alignment of the Economic and Social Plan (PES) and the State Budget (OE), management by objectives and redefining the role of the state in some areas socio-economic as well as the entry of new actors in the process management of public policies, for example, creating public-private partnerships in managing customs.

It is argued that new forms of governance proposed by the NPM and the IG, highlight new organizational 
dimensions in the process of governance in Mozambique adopted a consequence of institutional reforms such as decentralization, devolution and delegation in public administration as well as mechanisms accountability to society, engagement and participation of various stakeholders in the formulation and implementation of public policies. It is, according to the argument Alves $(2003, \mathrm{p}, 133)$ that the changes brought about by the reforms reflect a reordering process, organization and interaction between the bureaucratic organizational structures and new patterns emerging. According to this author, in a process of change, structures up to succeed each other, not totally eliminate, but rather swapped up and absorb some elements of a partially or another.

According to Medeiros (2006, p. 151) "is not, therefore, the direct application of the principles of administration of the private sector in public administration, nor the abandonment of the categories of classical bureaucracy at once. Implies yes, appropriations and adaptations of the principles used by private organizations in order to give the government a model that effectively help fulfill its purpose". Thus, new structures emerging from the NPM and the IG in Mozambique would be contained in the form outlined by organizational ideal typical bureaucratic without it, signifies a break with the model, but adapted with a view to greater flexibility and dynamism of organizations towards the demands of contemporary society.

\section{References}

Abrucio, F. (1997). O impacto do modelo gerencial na administração pública: breve estudo sobre a experiência internacional recente. Cadernos ENAP, 10, 1-56.

Alves, S. (2003). Racionalidade, carisma e tradição nas organizações empresariais contemporâneas. Recife: Ed. UFPE.

Aragão, C. (1997). Burocracia, eficiência e modelos de gestão pública: um ensaio. Revista do Serviço Público, 48(3), 105-134.

Barzelay, M. (2001). The new public management: a bibliographical essay for Latin American (and other) scholars. International public management journal, 3(2), 229-265. http://dx.doi.org/10.1016/S1096-7494(00)00038-6

Börzel, T. A. (1998). Organizing Babylon-On the Different Conceptions of Policy Networks. Public administration, 76(2), 253-273. http://dx.doi.org/10.1111/1467-9299.00100

Caiden, G. (1994). Administrative reform. In R. Baker (Ed.), Comparative public management: Putting U. S. Implementation and public policy in context (pp. 107-118). Westport: Praeger Publishers.

Crozier, M. (1981). O fenômeno burocrático, Ed. Universidade de Brasília: Brasília, 257-303.

Denhardt, R. B., \& Denhardt, J. V. (2000). The new public service: Serving rather than steering. Public administration review, 60(6), 549-559. http://dx.doi.org/10.1111/0033-3352.00117

Ferlie, E. et al. (1996). The new public management in action. Oxford: Oxford University Press. http://dx.doi.org/10.1093/acprof:oso/9780198289029.001.0001

Lapassade, G. (1967). Burocracia, burocratismo, burocratização. In E. Morin (Org), A burocracia (pp. 17-30). Lisboa: Ed. Socicultur.

Larbi, G. (1999). The new public management approach and crisis states. United Nations Research Institute Social Development, sep. Discussion Paper n. 112,

Medeiros, P. (2006). Do modelo racional-legal ao paradigma pós-burocrático: reflexões sobre a burocracia estatal. Organização e Sociedade, 13(37), 143-160.

Merquior, J. G. (1990). De Rousseau a Weber, Ed. Guanabara Koogan: Rio de Janeiro.

Mesquita, A., \& Ferreira, S. (1997). Strengthen the public service and enhance citizenship: the Australian option. Public Service Magazine, 3, 36-61.

Morin, E. (1967). O que não é burocracia. In: Morin, E. (Org), A burocracia (pp. 33-38). Lisboa: Ed. Socicultur.

Olsen, J. P. (2006). Maybe it is time to rediscover bureaucracy. Journal of Public Administration Research and Theory, 16(1), 1-24. http://dx.doi.org/10.1093/jopart/mui027

Olsen, J. P. (2007). The ups and downs of bureaucratic organization. Center for European Studies. Working Paper. set, n. 14.

Osborne, D., \& Gaebler, T. (1995). Reinventando o Governo: como o espírito empreendedor está transformando o setor público (8th ed.). Brasília: MH Comunicação.

Peci, A., Pieranti, O., \& Rodrigues, S. (2008). Governança e New Public Management: convergências e 
contradições no contexto brasileiro. Organização e Sociedade, 15(46), 39-55.

Polidano, C. (1999). The new public management in Developing Countries, IDPM Public Policy and Management, nov. Working Paper no. 13.

Pollitt, C., \& Bouckaert, G. (2002). Avaliando reformas da gestão pública: uma perspectiva internacional. Revista do Serviço Público, 53(3), 5-30.

Rondinelli, D. A. (1990). Decentralization, territorial power and the state: a critical response. Development and Change, 21(3), 491-500. http://dx.doi.org/10.1111/j.1467-7660.1990.tb00385.x

Rua, M. (1997). Desafios da administração pública brasileira: governança, autonomia, neutralidade. Revista do Serviço Público, 48(3), 133-152.

Secchi, L. (2009). Organizational models and public management reforms. Revista de Administração Pública, 43(2), 347-369. http://dx.doi.org/10.1590/S0034-76122009000200004

Soiri, L. (1999). Mozambique: Learning to walk with a cane borrowed? Links between decentralization and poverty alleviation. European Centre for Development Policy Management. Maastricht.

Tohá, C., \& Solari, R. (1997). A modernização do Estado ea gerência pública. Revista do Serviço Público, ENAP, Brasília, Ano, 48(3), 84-101.

Touraine, A. (1967). A alienação burocrática. In E. Morin (Org), A burocracia (pp. 257-303). Lisboa: Ed. Socicultur.

Weber, M. (1999). Economia e Sociedade (vol. 2). Revisão técnica de Gabriel Cohn. Brasília: Ed. UNB.

Wuyts, M. (1995). Foreign aid, structural adjustment, and public management: The Mozambican experience, nov. Working Papers Series. 206.

\section{Copyrights}

Copyright for this article is retained by the author(s), with first publication rights granted to the journal.

This is an open-access article distributed under the terms and conditions of the Creative Commons Attribution license (http://creativecommons.org/licenses/by/3.0/). 